\title{
1969 PROGRAM
}

\section{AMERICAN SOCIETY FOR \\ CLINICAL INVESTIGATION, INC. \\ 61ST ANNUAL MEETING}

Including programs for

American Federation for Clinical Research, Inc.

The Association of American Physicians

M O.N D A Y, MA Y 5

PENNSYLVANIA ROOM, HADDON HALL

A TLA N T I C I T Y 


\title{
American Society for Clinical Investigation, Inc.
}

\author{
6IST ANNUAL MEETING
}

MONDAY, MAY 5

\author{
M O R N I N G \\ 9:00 a.m., Pennsylvania Room, Haddon Hall
}

FIRST BUSINESS SESSION

THE PRESIDENT'S ADDRESS

\section{SCIENTIFIC SESSION}

Chairman: Dr. Arnold S. Relman

(The presentation of each paper will be limited to $10 \mathrm{~min}$.)

1. Vitamin $\mathrm{B}_{12}$-Dependent Methylmalonic Aciduria: Defective Cobamide Coenzyme Metabolism in Cultured Fibroblasts. L. E. Rosenberg, A-Ch. Lilljeqvist,* Y. E. Hsia,* and F. M. Rosenbloom,* New Haven, Conn. (222)

2. Demonstration of the Polyol Pathway in Rabbit and Human Aorta. R. S. Clements, JR.,* A. D. Morrison,* and A. I. Winegrad, Philadelphia, Pa. (50)

3. Alpha Cell Function in Man. E. Aguilar-Parada,* A. M. Eisentraut,* and R. H. Unger, Dallas, Tex. (2)

4. Quantitative Relationships of Fetal and Maternal Pituitary-Adrenal Systems. B. T. JAcKson,* H. F. J. RAUSchecker,* and G. J. Piasecki,* Boston, Mass. (introduced by R. H. Egdahl). (130)

5. The Relationship of Steroid Structure to Gene Expression in HTC Cells; A Unifying Concept. H. H. SAMuels* and G. M. Tomkins,** Bethesda, Md. (233)

6. Stimulation of Gut Electrolyte Secretion by Prostaglandins, Theophylline, and Cholera Exotoxin. W. B. Greenough III,* N. F. Pierce,* Q. Al Awqati,* and C. C. J. Carpenter, Baltimore, Md. (104)

7. Ileal Electrolyte Transport in Normal Man. L. A. TurNBerg,* F. A. Bieberdorf,* and J. S. Fordtran, Dallas, Tex. (271)

\footnotetext{
* Denotes nonmember, ASCI, AFCR, or AAP.

** Denotes emeritus member ASCI or senior member AFCR.

Names with no following symbol are active members of the society to which the abstract was submitted.

( ) Abstract number.

$\ddagger$ The President gratefully acknowledges the valuable assistance of the Subsection Chairmen in the selection of this program.
}

8. The Nature of the Defect in Intestinal Calcium Absorption in Chronic Renal Disease. L. V. Avioli, S. W. LeE,* S. J. Birge,* E. Slatopolsky,* and H. F. Deluca,* St. Louis, Mo. and Madison, Wis. (12)

9. Natriuretic Activity in Plasma and Urine of Salt-Loaded Man and Sheep. J. H. Laragh, J. E. Sealey,* and J. D. Kirshman,* New York. (157)

10. Elevated Intrarenal Pressure in Essential Hypertension. J. Lowenstein,* D. S. Baldwin,** and H. Chasis,** New York. (170)

11. Left Ventricular Pressures in Acute Myocardial Infarction. P. Hamosh,* I. M. Khatri,* and J. N. Cohn, Washington, D. C. (107)

12. Essential Role of Platelets in Maintaining Vascular Integrity of Organs during Normothermic Perfusion In Vitro. M. Gimbrone, JR.,* R. Cotran,* J. H. JandL, J. Folkman,* and R. H. Aster, Boston, Mass. (92)

\section{A F T ER N OON}

2:00 p.m., Pennsylvania Room, Haddon Hall

\section{SECOND BUSINESS SESSION}

\section{SCIENTIFIC SESSION}

Chairman: Dr. Lewis W. Wannamaker

13. The Regulation of Thrombopoiesis. L. A. HARKer,* Seattle, Wash. (introduced by C. A. Finch**). (112)

14. Treatment of Red Cell Aplasia with Immunosuppressive Drugs. S. B. Krantz,* V. KaO,* and E. B. Brown, Bethesda, Md., Chicago, Ill., and St. Louis, Mo. (introduced by L. O. Jacobson**). (148)

15. Measurement of Clinical Blood Levels of Digoxin by Radioimmunoassay. T. W. SMItH* and E. HABER, Boston, Mass. (249)

16. Reversal of Digoxin Toxicity with Specific Antibodies. D. H. Schmidt* and V. P. Butler, JR.,* New York. (introduced by R. M. Harvey**). (237)

17. Hypoxanthine-Guanine Phosphoribosyltransferase (PRT) Deficiency: Activity in Normal, Mutant, and Heterozygote Cultured Human Skin Fibroblasts. W. Y. Fuj IмOTo* and J. E. SeEgmiller, ** Bethesda, Md. (85) 
18. IgE Deficiency Associated with Chronic Sinopulmonary Infection. W. A. CaIn;* A. J. Ammann,* R. Hong,* K. IshizakA,* and R. A. Good,** Minneapolis, Minn. (38)

19. Soluble Human Transplantation Alloantigens. D. L. Mann,* G. N. Rogentine,* J. L. Fahey, and S. NathEnson,* Bethesda, Md. and New York. (177)

20. Protein A : An Antiphagocytic Factor of Staphylococcus aureus. J. H. Dossett,* G. Kronvall,* R. C. Williams, JR., and P. G. QUIE, Minneapolis, Minn. (68)

21. Heme Deficiency of Beta Chains: A Cause of Hemoglobin Precipitation in Congenital Heinz Body Hemolytic Anemia (CHBHA). K. Winterhalter* and H. JAcob, Zurich, Switzerland and Minneapolis, Minn. (285)
22. Defect in $\beta$-Thalassemic Cell-Free System: Unresponsiveness to Ribosomal Subunits and an Inhibitor of Protein Synthesis. J. E. Fuhr,* C. Natta,* P. A. Marks, and A. BANK,* New York. (84)

23. Hepatitis Virus and Australia Antigen. B. S. Blumberg, B. J. S. Gerstley,* W. T. London,* I. Millman,* A. I. Sutnick,* and V. Zavatone,* Philadelphia, Pa. (28)

24. The Immunity Produced in Human Volunteers by the Administration of Meningococcal Polysaccharides. E. C. Gotschlich,* I. Goldschneider,* M. S. Artenstein,* and T. Y. Lru,* Washington, D. C. and Brookhaven, N. Y. (introduced by M. McCarty**). (100)

25. Tracheobronchial Clearance in Chronic Obstructive Lung Disease. R. V. Lourenco,* T. O. Anderson,* and H. Levine,* Chicago, Ill. (introduced by H. F. Dowling**). (169)

\title{
Joint Program with the American Federation for Clinical Research, Inc.
}

\author{
SUNDAY AFTERNOON, MAY 4
}

\section{CARDIOVASCULAR PHYSIOLOGY \\ 2:00 p.m., Carolina Room, Chalfonte Chairman: Dr. John Ross, Jr.}

1. Plasma Catecholamines in Hypertensive and Psychiatric Disorders. B. Portnoy, K. Engelman, and R. Wyatt,* Bethesda, Md. AFCR

2. Increased Myocardial Myosin ATPase Activity Associated with an Increased Myocardial Contractility in $\mathrm{Hy}-$ perthyroid Guinea Pigs. M. J. Goodkind,* G. E. DamвACH,* and R. J. Luchi, Philadelphia, Pa. ASCI (98)

3. The Influence of Hyperthyroidism on the Effects of Norepinephrine on Myocardial Adenyl Cyclase Activity and Myocardial Contractile State. C. L. Skelton,* G. S. Levey,* and S. E. Epstein, Bethesda, Md. AFCR

4. Inotropic and Chronotropic Responses to Conversion from Ventricular Fibrillation in Intact Dogs and Isolated Hearts. F. M. Abboud, D. G. Pansegrau,* and H. E. MAYER,* Iowa City, Iowa. ASCI (1)

5. Human Myocardial Lactic Dehydrogenase (LDH) Patterns in Neonates, Ischemic Heart Disease, and Hypertrophy. J. M. Ballo,* V. S. Mathur,* and J. V. Messer, Boston, Mass. (introduced by H. S. Sise). AFCR

6. Altered Biosynthesis of $\mathrm{LDH}$ Subunits in Myocardium and Skeletal Muscle of Congenitally Cyanotic Patients. M. Altman,* J. Scheuer,* and E. D. Robin,** Pittsburgh, Pa. ASCI (7)

7. Pulmonary Gas Exchange in Cardiogenic and Hypovolemic Shock. N. H. Edelman,* L. Hirsch,* J. Gorfinkel,* A. Gottschalk,* and A. P. Fishman,** Chicago, Ill. AFCR
8. Regional Pulmonary Perfusion after Myocardial Infarction. D. J. Strieder, L. M. Valenca,* E. F. Parsons,* and H. Kazemi, Boston, Mass. AFCR

9. Measurement of $V_{\max }$ in Auxotonic Systoles from the Rate of Relative Increase of Isovolumic Pressure: $(\mathrm{dp} / \mathrm{dt}) / \mathrm{kP}$. M. J. Wolk,* J. F. Keefe,* O. H. L. Bing,* L. J. Finkelstein,* and H. J. Levine, Boston, Mass. ASCI (288)

10. Early Diagnosis and Treatment of Rejection following Cardiac Transplantation. D. C. Harrison, J. S. SchroeDer,* R. Popp,* and N. E. Shumway,* E. B. Stinson,* and E. Dong, Jr.,* Palo Alto, Calif. AFCR

11. Characterization of Oxygen Receptors in the Human Umbilical Artery. J. Jones,* E. Engelman,* J. Waldman,* and K. Melmon, San Francisco, Calif. ASCI (133)

\section{DERMATOLOGY}

2:00 p.m., West Room, Haddon Hall

Chairman: Dr. Leonard C. Harber

1. Erythropoietic Protoporphyria: A Misnomer. P. ScholNICK,* H. Marver, and R. Schmid,** San Francisco, Calif. AFCR

2. A Double-Blind Study of 6-Azauridine Triacetate in Psoriasis. W. R. Vogler and S. Olansky,** Atlanta, Ga. AFCR

3. Analysis of the Increase of Sweat Rate Brought About by Recruitment or Enhancement of Secretion. J. C. Fasciolo,* B. B. Joh nson,* and G. Totel,* Urbana, Ill. (introduced by Robert E. Johnson**). ASCI (73) 
4. Molecular Aspects of Cutaneous Photosensitization by Psoralens. M. A. PAthaK** and D. KRÄMER,* Boston, Mass. AFCR

5. RNA-Mediated Pigment Induction in Amelanotic Malignant Melanocytes. G. LIPKIN, New York. AFCR

6. A Uniquely Oriented Component of Epidermis. L. A. Goldsmith* and H. P. BAdEN, Boston, Mass. AFCR

7. An In Vivo Study of a Defect in DNA Synthesis in Xeroderma Pigmentosum (XP). J. H. Epstein,* K. Fukuyama,* W. L. Epstein,* and W. B. Reed, San Francisco, Calif. ASCI (72)

8. Development of Tolerance in New Zealand Mice. I. M. Braverman and J. Slesinski,* New Haven, Conn. AFCR

9. Solar Urticaria: Association of Serum Activity with an Antibody Other Than IgG or IgM. W. M. SAMS, JR., Rochester, Minn. AFCR

10. Variability of the Chemical Composition of Human Skin Surface Lipids. D. T. Downing, ${ }^{*}$ J. S. Strauss, ${ }^{* *}$ and P. E. Pochi, Boston, Mass. AFCR

11. Subcellular Localization of the Initial Reactions of Protein Synthesis in Epidermis and Hair Roots. I. M. FreEDBERG, Boston, Mass. AFCR

\section{ENDOCRINOLOGY}

\section{2:00 p.m., Pennsylvania Room III, Haddon Hall Chairman: Dr. Sidney H. Ingbar}

1. Effect of Sodium Loading in the Syndrome of Aldosteronism, Juxtaglomerular Hyperplasia, and Normal Blood Pressure. E. L. Bravo,* R. Brown,* and F. C. BArtTer, ${ }^{* *}$ Bethesda, Md. AFCR

2. Dissociation of Biological and Radioimmunological Disappearance Rates and Concentrations of Plasma ACTH in Man. G. M. Besser,* D. N. Orth, W. E. Nicholson,* and K. ABE,* Nashville, Tenn. AFCR

3. Chlorpropamide-Induced Release of Antidiuretic Hormone in Patients with Diabetes Insipidus. M. MILler and A. M. Moses, Syracuse, N. Y. AFCR

4A. Stimulation of Anterior Pituitary (AP) Adenyl Cyclase Activity (ACA), Cyclic 3'5' Adenosine-Monophosphate (CAMP), and LH Release by Hypothalamic Extract (HE). U. Zor,* T. KaneKo,* H. P. G. Sch NeIder,* S. M. McCann, and J. B. Field, Pittsburgh, Pa. and Dallas, Tex. ASCI (297)

4B. Median Eminence Stimulation of Growth Hormone (GH) and Thyrotropin (TSH) Secretion and the Pituitary Adenyl Cyclase System. A. L. Steiner,* G. T. Peake,* R. Utiger, and D. Kipnis, St. Louis, Mo. ASCI (256)

5. Myocardial Adenyl Cyclase: Activation by Thyroid Hormones and Evidence for Two Adenyl Cyclase Systems. G. S. Levey* and S. E. Epstein,* Bethesda, Md. (introduced by J. Wolff). ASCI (163)

6. Effects of Immunization of Baboons with Human Thyroid Tissue. G. N. Beall,* P. M. Daniel,* O. E. Pratt,* and D. H. Solomon, Torrance, Calif. ASCI (19)

7. Localization of Parathyroid Adenomas by Selective Venous Catheterization and Radioimmunoassay. R. E.
Reitz,* J. J. Pollard,* D. Fleischli,* C. A. Wang,* O. Cope,* T. M. Murray,* L. J. Deftos,* and J. T. Potts, JR., Boston, Mass. AFCR

8. Nondialyzable Urinary Hydroxyproline: An Index of Bone Formation? J. Haddad,* S. Birge, S. Cournaz,* and L. V. Aviolr, St. Louis, Mo. AFCR

9. Estradiol in Human Plasma: Demonstration of Elevated Levels in Gynecomastia and in Cirrhosis. S. G. Korenman,* L. E. Perrin,* and T. McCallum,* Torrance, Calif. (introduced by K. Wasserman). ASCI (144)

10. Plasma 17-Hydroxyprogesterone as an Index of Leydig Cell Function. C. A. Strott and M. B. Lipsetr, ${ }^{* *}$ Bethesda, Md. AFCR

11. Amelioration of Hypertriglyceridemia by Progestational Drugs in Familial Type V Hyperlipoproteinemia. C. J. Glueck,* W. V. Brown,* R. I. Levy, H. Greten,* and D. S. Fredrickson,* Bethesda, Md. AFCR

\section{GASTROENTEROLOGY}

\section{2:00 p.m., Windsor Room, Haddon Hall Chairman: Dr. Marvin H. Sleisenger}

1. Albumin Synthesis Dependent on Tryptophan and Isoleucine. M. A. Rothschild, M. Oratz,* J. Mongelli,* and S. S. SchreIber,* New York. ASCI (224)

2. Phenobarbital-Induced Rise in Bilirubin Conjugation In Vivo. S. H. RoBinson, Boston, Mass. AFCR

3. Phenobarbital Prevents Chemical Porphyria. L. KAUfMAN* and H. S. Marver,* San Francisco, Calif. (introduced by R. Schmid**). ASCI (137)

4. Phenobarbital Inhibition of the Ethanol-Induced Fatty Liver. R. S. Koff, S. Lui,* E. A. Carter,* and K. J. ISSELBACHER, ** Boston, Mass. AFCR

5. Metabolism of Bile Salt in the Fetal Dog. R. A. SMallwood,* R. Lester, G. J. Piasecki,* H. F. J. RauSCHECKER,* and B. T. JACKson,* Boston, Mass. ASCI (247)

6. Cholesterol Solubility and Bile Composition after Interruption of the Enterohepatic Circulation (EHC) in the Rhesus Monkey. R. H. Dowling,* E. MAck,* and D. M. Small, Boston, Mass. AFCR

7. Adult Formiminotransferase Deficiency: A New Entity. R. H. Herman,** N. S. Rosensweig, F. B. Stifel, and Y. F. Herman,* Denver, Colo. AFCR

8. Organ Culture of Human Small Intestine. J. S. TRIER and T. H. Browning,* Albuquerque, N. M. and Boston, Mass. ASCI (269)

9. Location of Lipid Reesterifying Enzymes in the Small Intestine and Effects of Jejunectomy on Ileal Enzyme Levels. J. B. Rodgers, JR., Albany, N. Y. AFCR

10. Enzyme Activity of the Intestine. J. W. Anderson* and D. ZAKIM,* San Francisco, Calif. (introduced by M. H. Sleisenger). ASCI (8)

11. Ferrous Iron Oxidation by Intestinal Mucosal Homogenates and Its Possible Relationship to Iron Absorption. J. ManIs,* New York. (introduced by D. Schachter). ASCI (176) 


\section{GENETICS}

\section{2:00 p.m., Garden Room, Haddon Hall Chairman: Dr. Howard H. Hiatt}

1. Renal and Intestinal Hexose Transport in the GlucoseGalactose Malabsorption Syndrome. L. J. ElsAs, R. E. Hillman,* J. H. Patterson,* and L. E. Rosenberg, New Haven, Conn. and Atlanta, Ga. AFCR

2. Correction of the Biochemical Defect of the Hurler and Hunter Syndromes in Culture by Diffusible Factors. J. C. Fratantoni* and E. F. Neufeld,* Bethesda, Md. (introduced by J. E. Rall**). ASCI (82)

3. Malignant Transformation in Fanconi's Anemia. $H$. Dosik,* L. Y. Hsu,* G. J. Todaro,* S. L. LeE,** K. Hirschiorn,** E. S. Selirio,* and A. A. Alter, New York and Bethesda, Md. AFCR

4. Racial Polymorphisms in Human Chromosomes. H. A. Lubs* and F. H. Rudde,** New Haven, Conn. (introduced by S. Lipsky). ASCI (173)

5. Translational Control of Gene Expression. T. Gelehrter and G. Tomkins,* Bethesda, Md. AFCR

6. Regulation of Gene Expression in Reticulocytes by Changes in Ribonuclease Activity. E. R. BuRKa,* Philadelphia, Pa. (introduced by F. R. Miller**). ASCI (36)

7. Mild Homozygous $\beta$-Thalassemia (Thal). The Result of Interaction with an $\alpha$-Thal Gene. Y. W. KAN* and D. G. Nathan, Boston, Mass. AFCR

8. Enzymic Aggregation in Studies of Normal and Mutant Enzymes. H. N. Kirkman, Chapel Hill, N. C. ASCI (140)

9. A. Hyposynthetic Genetic Variant of C'3 F. C. A. Alper* and F. S. Rosen, Boston, Mass. ASCI (6)

10. Hereditary Nephritis with Nerve Deafness: Immunofluorescent Studies on the Kidney. G. S. SpeAr, J. M. Whitworth,* and B. W. Konigsmark,* Baltimore, Md. AFCR

11. A New Syndrome of Hereditary Thrombocytopathia, Nephritis, and Deafness. C. J. Epstein, I. L. London,** M. Sahud,* J. Goodman,* C. Piel,* and M. Bernfield,* San Francisco and Palo Alto, Calif. AFCR

\section{HEMATOLOGY}

\section{2:00 p.m., Vernon Room, Haddon Hall Chairman: Dr. Paul A. Marks}

1. Genetic and Diagnostic Studies Using a New Assay for Factor XIII (FSF). A. Atencio,* I. Urayama,* L. LoRAND,* and D. Y. Y. Hsia,** Evanston and Hines, Ill. AFCR

2. In Vitro Detection of Antiplatelet Antibody in Patients with ITP and SLE. S. Karpatkin and G. W. Siskind,* New York. AFCR

3. Studies of a Humoral Factor Affecting Platelet Production in Man. L. W. Sullivan, Boston, Mass. AFCR

4. Hemoglobin Philly ( $\beta-35$ Tyr-Phe) : Clinical and Chemical Consequences of the Loss of a Pair of Interchain
Hydrogen Bonds. R. F. Rieder, F. A. Oski, and J. B. ClegG,* Philadelphia, Pa. AFCR

5. The Correction of Glutathione Reductase Deficiency by Riboflavin Administration. E. Beutler, Duarte, Calif. ASCI (22)

6. Intracellular Iron Defect in Alcoholism. R. EICH NER* and R. S. Hillman, Seattle, Wash. AFCR

7. Bilirubin Production from Erythropoietic and Nonerythroid Sources in Experimental Iron Deficiency Anemia. S. H. Robinson, * Boston, Mass. (introduced by Howard H. Hiatt). ASCI (221)

8. Defective Candidacidal Activity in Chronic Granulomatous Disease Neutrophils: Correction by Redox Dyes. R. I. Lehrer,* San Francisco, Calif. (introduced by M. J. (line). AFCR

9. Isolation and Characterization of Phytohemagglutinin Receptor Sites. S. Kornfeld* and R. Kornfeld,* St. Louis, Mo. (introduced by Carl V. Moore**). ASCI (145)

10. Protein-Quinone Interaction: Induction of Indirect Antiglobulin Tests by $\alpha$-Methyl DOPA. A. J. GottLieB and H. A. Wurzes,* Philadelphia, Pa. AFCR

11. Chloramphenicol and Protein Synthesis in Bone Marrow Mitochondria. O. J. Martelo,* D. R. Manyan,* U. S. Smith,* G. K. Arimura,* and A. A. Yunis, Miami, Fla. ASCI (178)

\section{IMMUNOLOGY AND CONNECTIVE TISSUE}

\section{2:00 p.m., Rutland Room, Haddon Hall \\ Chairman: Dr. K. Frank Austen}

1. Studies with a Humoral Immunoregulatory Factor Isolated from the Plasma Alphaglobulins (IRA). S. R. Cooperband,* R. C. Davis,* K. Schmid,* and J. A. Mannick, Boston, Mass. ASCI (57)

2. In Vitro Studies of Anergy in Sarcoidosis; Demonstration of an Early Block in the PPD Response. F. P. AlepA* and J. E. Sherlock,* Washington, D. C. (introduced by N. J. Zvaifler). AFCR

3. In Vitro Assay for Delayed Hypersensitivity (DH) in Man. R. E. Rocklin,* O. L. Meyers,* and J. R. David,** Boston, Mass. AFCR

4. Studies of Human Amyloid. D. Zucker-FrankLin,* M. Pras,* and E. C. Franklin, New York. ASCI (298)

5. Complement Metabolism in Patients with Hereditary Angioedema (HAE). C. B. Carpenter,* S. Ruddy,* I. H. Shehadeh,* D. J. Stechschulte,* H. J. MÜllerEberhard, J. P. Merrill,** and K. F. Austen, Boston, Mass. and LaJolla, Calif. ASCI (44)

6. Serum and Cerebral Spinal Fluid (CSF) Complement and Serum Autoantibody Patterns in Systemic Lupus Erythematosus (SLE) Nephritis and Central Nervous System (CNS) Disease. L. D. Petz, G. C. Sharp, W. S. Irvin,* and N. Cooper,* LaJolla, Calif. AFCR

7. Biosynthesis of the Carbohydrate Moieties of Immunoglobulin and Its Intracellular Transport. J. W. UHR, D. Zagury,* I. Schenkein,* J. D. Jamieson, ${ }^{*}$ and G. E. PALAdE,* New York. ASCI (272) 
8. Structural Gene Defects and Preponderance of $\gamma$ G3 Subgroup in Patients with Hypogammaglobulinemia. W. J. Yount,* R. Hong,* M. Seligmann,* and H. G. Kunkel,** New York, Minneapolis, Minn., and Paris, France. ASCI (293)

9. Relation between Metabolic Properties and Serum Concentration of IgG-Subclasses in Man. A. Morell,* W. Terry, and T. Waldmann, Bethesda, Md. AFCR

10. Deficiency of Immunologic Tolerance in Murine Systemic Lupus Erythematosus (SLE). P. J. Staples,* A. D. Steinberd,* and N. Talal, Bethesda, Md. ASCI (253)

11. Collagen: Molecular Alterations and Biologic Activity. K. H. Stenzel, M. W. Dunn,* T. Miyata,* and A. L. Rubin, ${ }^{* *}$ New York. AFCR

\section{INFECTIOUS DISEASES}

2:00 p.m., Viking Room, Haddon Hall Chairman: Dr. Calvin M. Kunin

1. Correction of Oxidative Deficiencies of Leukocytes in Chronic Granulomatous Disease (CGD). R. L. BAEHNER,* M. L. Karnovsky,* and D. G. Nathan, Boston, Mass. (introduced by C. A. Janeway**). ASCI (14)

2. Opsonins following Immunization of Man with Meningococcal Capsular Polysaccharides. R. B. Roberts,* New York. (introduced by J. G. Hirsch**). ASCI (219)

3. Identification of the Antigen Involved in Experimental Streptococcal Glomerulonephritis. K. L. Vostr, L. H. Lindberg,* and S. Raffel,* Palo Alto, Calif. AFCR

4. Bacterial Antagonism: Viridans Streptococci vs. the Pneumococcus. W. G. Johanson,* J. P. Sanford, A. K. Pierce, and R. Blackstock,* Dallas, Tex. AFCR

5. Alteration of the Bactericidal Activity of Polymorphonuclear Neutrophils by an NADH Oxidase Inhibitor. G. L. Mandell,* W. Rubin,* and E. W. Hook, New York. ASCI (175)

6. Serum Antibody Protection against Rhinovirus Infection in Volunteers: A Phenomenon Related to Challenge Dose. W. P. Edmondson, JR.,* and J. M. Gwaltney, JR., Charlottesville, Va. AFCR

7. Immunologic Distinction between Serum and Infectious Hepatitis. R. L. Hargrove,* G. H. Jefrries, and A. M. Prince,* New York. ASCI (111)

8. Protection against Intracellular Infection by Synthetic Polyanions or Unrelated Intracellular Organisms. J. Remington and T. Merigan, Palo Alto, Calif. AFCR

9. The Effect of Hypertonic Saline and Urea on Human PMN Adhesion, Motility, and Phagocytosis. R. E. Bryant, Z. A. McGee, and M. G. Koenig, Nashville, Tenn. AFCR

10. Effect of Suppression of Fever on Mortality Rate in Experimental Pneumococcal Sepsis. J. KLASTERSKY* and E. H. Kass,** Boston, Mass. AFCR

11. Chemical Modification of $\gamma \mathrm{G}$ Antistaphylococcal Antibodies: Effect on Opsonic Activity. R. P. Messner, C. W. Parker,* and R. C. Williams, JR., Minneapolis, Minn. and St. Louis, Mo. AFCR

\section{KIDNEY AND ELECTROLYTE}

\section{2:00 p.m., Pennsylvania Room II, Haddon Hall Chairman: Dr. Norman G. Levinsky}

1. Relationship between Peritubular Capillary Protein Concentration and Fluid Reabsorption by the Rat Proximal Tubule. B. M. Brenner,* K. H. FalchuK,* R. I. KeimowITz,* and R. W. Berliner,** Bethesda, Md. ASCI (33)

2. Vasopressin $(\mathrm{ADH})$ and the Inhibition of Water Diuresis in Adrenal Insufficiency. H. H. GREEN,* A. R. HARRington,* and H. Valtin, Hanover, N. H. ASCI (102)

3. Dialyzable Inhibitor of Toad Bladder Sodium Transport in Plasma of Volume-Expanded Dogs. V. M. Buckalew, Jr., F. J. Martinez,* and W. E. Green,* Atlanta, Ga. AFCR

4. Functional Significance of the Distribution of Na-KATPase within the Kidney. E. K. Hendler,* J. Torretti,* E. Weinstein,* and F. H. Epstein, New Haven, Conn. ASCI (120)

5. Stimulation of Active Chloride Secretion in Small Intestine by Cholera Exotoxin. M. Field,* D. Fromm,* C. K. Wallace,* and W. B. Greenough III,* Boston, Mass. and Baltimore, Md. (introduced by P. S. Norman). ASCI (77)

6. An Effect of Aldosterone on $\mathrm{Na}^{+}$Transport in the $\mathrm{Ab}$ sence of Oxidative Metabolism. D. Goodman,* J. Allen,* and H. Rasmussen, Philadelphia, Pa. ASCI (99)

7. Kinetics of $\mathrm{Na}$ Transport: Dual Effects of $\mathrm{ADH}$. A. L. Fins, New Haven, Conn. AFCR

8. Patterns of Release and Identification of Renal Antihypertensive Substances Produced by Renal Ischemia. J. C. McGiff,* N. A. Terragno,* A. J. Lonigro,* and K. K. F. NG,* St. Louis, Mo. (introduced by $R$. Wegria**). ASCI (182)

9. Defect in Urinary Acidification Induced In Vitro by Amphotericin B. P. R. Steinmetz* and L. R. LAwson,* Boston, Mass. (introduced by $\mathrm{H}$. S. Frazier). ASCI (257)

10. The Relationship of Extracellular Volume and $\mathrm{CO}_{2}$ Tension to Renal Bicarbonate Reabsorption. N. A. KURTzman, Houston, Tex. AFCR

11. On the Effect of Nephron Reduction on Bicarbonate Transport in the Mammalian Nephron. H. Lubowitz,* M. L. Purkerson,* and N. S. Bricker, St. Louis, Mo. (introduced by C. G. Harford**). ASCI (172)

\section{METABOLISM}

\section{2:00 p.m., Pennsylvania Room I, Haddon Hall Chairman: Dr. Donald S. Fredrickson}

1. Effects of Glucagon and Parathyroid Hormone on Plasma and Urinary Cyclic AMP in Man. N. I. Kaminsky,* A. E. Broadus,* J. G. Hardman,* H. E. Ginn,* E. W. Sutherland,* and G. W. Liddle,** Nashville, Tenn. ASCI (134)

2. Inhibition of Cyclic 3'5' Adenosine Monophosphate-Activated Lipase. P. H. Schreibman,* D. E. Wilson,* and R. A. Arky,* Boston, Mass. (introduced by S. H. Ingbar). ASCI (238) 
3. Adipose Tissue Cellularity and Epinephrine-Stimulated Lipolysis in Obese and Nonobese Children. J. KnIttle and F. Ginsberg-Fellner,* New York. AFCR

4. Hyperaminoacidemia: Possible Mechanism of Hyperinsulinemia in Obesity. P. Felig, E. Marliss,* and G. F. Cahill, JR.,** Boston, Mass. AFCR

5. The Effect of Fasting, Dietary Composition, and Actinomycin on the Insulin Secretory System in the Rat. N. GREY,* S. GoldRing,* and D. Kipnis, ${ }^{* *}$ St. Louis, Mo. AFCR

6. Suppression of Glucagon Release by Hypoglycemic Sulfonylureas. E. SAmols* and J. M. Tyler,* Augusta, Ga. (introduced by A. J. Bollet). ASCI (231)

7. Isolation of a Zinc-Containing $\alpha_{2}$-Macroglobulin from Human Serum. A. F. PARISI* and B. L. VAlleE,** Boston, Mass. ASCI (200)

8. Demonstration of Cholesterol Feedback Deletion in Intact Hepatoma-Bearing Rats. L. A. BRICKER* and M. D. Siperstein, Dallas, Tex. ASCI (35)

9. Familial Type II Hyperlipoproteinemia: A Defect of Beta Lipoprotein Apoprotein Catabolism? T. LANGER,* W. Strober,* and R. I. Levy,* Bethesda, Md. (introduced by D. S. Fredrickson). ASCI (156)

10. Oral Phosphate Therapy in Experimental Hypercalcemia. S. W. Spaulding and M. Walser, ${ }^{* *}$ Baltimore, Md. AFCR

11. Physiological and Biochemical Evidence Exempting the Renal Medulla in the Experimental Renal Tubular Dysfunction of Patients with Hereditary Fructose Intolerance (HFI). J. F. Kranhold,* D. Loh,* and R. C. MorRIS, JR.,* San Francisco, Calif. (introduced by R. J. Havel). ASCI (147)

\section{NEOPLASIA}

\section{2:00 p.m., Solarium, Haddon Hall Chairman: Dr. Emil Frei III}

1. The Growth Fraction and Proliferative Rate of Leukemic Cells in Patients with Slowly Progressive Acute Leukemia. B. Clarkson,* M. Ogawa,* A. Todo,* and J. FRIED, New York. (introduced by D. A. Karnofsky**). ASCI (49)

2. Multiple Myeloma: Plasma Cell Gamma Globulin Synthesis and Total Body Tumor Cell Mass. S. E. Salmon and B. A. Smith,* San Francisco, Calif. AFCR

3. Host Effects of L-Asparaginase Treatment. J. P. WhITECAR, JR., J. E. HARris,* G. P. Bodey,* and E. J. FREIREICH, ** Houston, Tex. AFCR

4. Asparagine Synthetase in Human Leukemia: A Mechanism of Resistance to L-Asparaginase. C. M. HASKELL and G. P. Canellos, Bethesda, Md. AFCR

5. Adverse Effect of Antibiotics on Cyclophosphamide Chemotherapy. H. Bruckner,* Bethesda, Md. (introduced by E. Henderson). AFCR

6. Autologous and Allogeneic Canine Bone Marrow Grafts following Cyclophosphamide (CY). R. B. Epstein, R. Storb,* R. Rudolph,* R. A. Clift,* and E. D. Thomas,** Seattle, Wash. AFCR

7. Serum $\alpha$-Fetoprotein $(\alpha-F P)$ in Cancer Patients. E. W. Hull,* C. G. Moertel,* and P. P. Carbone, Bethesda, Md. and Rochester, Minn. AFCR
8. Gene Loss in Human Teratomas : Evidence for CrossingOver. D. Linder,* San Francisco, Calif. (introduced by N. L. Petrakis**). ASCI (168)

9. Experimental Induction of Myelofibrosis with Myeloid Metaplasia. M. S. Tobin, S. A. P. Argano,* and D. M. SpaIn,* Brooklyn, N. Y. AFCR

10. Defective Cell Differentiation and Abnormal Methylation of tRNA in Breast Cancer Cells. R. W. Turkington,* Durham, N. C. (introduced by J. C. Greenfield). ASCI (270)

11. DNA Polymerase: Abnormalities in Rat and Human Cancers. J. Laszlo, P. Ove,* W. W. Shingleton,* and H. P. Morris,* Durham, N. C. and Washington, D. C. AFCR

\section{PULMONARY}

\section{2:00 p.m., Music Room, Chalfonte \\ Chairman: Dr. Gerard M. Turino}

1. Pulmonary Histamine Dynamics with Hypoxia and 48/80. R. E. Brashear, R. R. Martin, and J. C. Ross, Indianapolis, Ind. AFCR

2. Uneven Ventilation within and between Regions of the Normal Lung Measured with Nitrogen-13. D. RosenzWeig, J. M. B. Hughes,* and T. Jones,* London, England. AFCR

3. Further Studies on the Inhibition of Surfactant by Plasma. Y. Heshiki,* J. W. C. Johnson,* and S. PerMUtT, ${ }^{* *}$ Baltimore, Md. AFCR

4. Observations on the Cause of Chronic Airway Obstruction. P. M. Stevens and B. F. Orman,* Houston, Tex. AFCR

5. Chronic Obstructive Lung Disease with Intermediate Deficiency of Alpha ${ }_{1}$-Antitrypsin. R. Fallat,* F. KUEPPers,* M. Powell,* E. Lilker,* J. A. Nadel, and J. F. Murray,** San Francisco, Calif. AFCR

6. Regional Distribution of Pulmonary Ventilation and Perfusion in Patients with Liver Cirrhosis. F. RufF,* J. J. Picken,* A. Aronoff,* J. Milic-Emili,* and D. V. BAtes, ** Montreal, Canada. ASCI (227)

7. Serum Elastase Inhibitor Deficiency and Alpha-1-Antitrypsin Deficiency in Patients with Obstructive Emphysema. R. M. Senior, G. M. Turino,** and I. Mandl,* New York and Washington, D. C. AFCR

8. The Effects of Nitrogen Dioxide and Nitrite Ion on Hydrogen Peroxide Metabolism in Alveolar Macrophages (AM) during Phagocytosis. J. B. L. GeE,* C. L. VASsallo,* P. Bell,* and R. E. Basford,* Pittsburgh, Pa. (introduced by J. D. Myers**). ASCI (88)

9. Hypoxic Ventilatory Drive in Normal Man. J. V. WeIL,* E. Byrne-Quinn,* I. D. Sodal,* R. F. Grover,** and G. F. Filley,* Denver, Colo. AFCR

10. Hypoxemia in Pulmonary Embolism. J. E. WILson III,* W. R. Harrell,* C. B. Mullins,* E. R. Winga,* R. L. Johnson, JR., and A. K. Pierce,* Dallas, Tex. ASCI (282)

11. Kinetics of Oxygen Uptake by RBC-Containing HB-S. H. H. Rotman,* R. A. Klocke,* K. Andersson,* L. D'Alecy,* and R. E. Forster, ${ }^{* *}$ Philadelphia, Pa. AFCR 


\title{
American Federation For Clinical Research, Inc.
}

\author{
26THANNUAL MEETING
}

SUNDAY MORNING, MAY 4

GENERAL MEETING

8:30 a.m., Pennsylvania Room, Haddon Hall, Dr. Jay P. Sanford, Presiding

BUSINESS SESSION

SCIENTIFIC SESSION

(The presentation of each paper will be limited to $12 \mathrm{~min}$.)
PRESIDENTIAL ADDRESS

INTERMISSION

SCIENTIFIC SESSION

(concluded)
1. A Distinct Rheumatic Disease Syndrome Associated with Antibody to a Particular Nuclear Antigen and Unusual Responsiveness to Corticosteroid Therapy. Gordon Sharp, William Irvin,* Halsted Holman,** and Eng TAN,** La Jolla, Calif.

2. Treatment of Vitamin D Resistance with 25-Hydroxycholecalciferol. Charles Y. C. Pak, Hector F. DE Luca,* José M. Chavez de los Rios,* and Tatsua SudA,* Bethesda, Md. and Madison, Wis.

3. Evidence That Dihydrotestosterone Formation May Be Involved in Prostatic Growth. R. E. GLoy NA* and J. D. Wilson, Dallas, Tex.

4. Human Plasma Kallikrein and Hageman Factor in Endotoxin Shock. J. W. MAson,* U. R. KLeEbERG,* and R. W. Colman, Boston, Mass.

5. Malabsorption of Polyglutamic Folic Acid Secondary to Oral Contraceptives. R. R. Streiff, Gainesville, Fla.
6. Radioimmunoassay of Gastrin. W. L. TrudeAU* and J. E. McGuigan, St. Louis, Mo.

7. Isolation and Characterization of an Inhibitor of Intestinal Calcium Transport in the Dog following Expansion of the Extracellular Space. Stanley J. Birge and Louis V. Avioli, St. Louis, Mo.

8. Production, Reversal, and Prevention of Experimental Hyaline Membrane Disease following Disseminated Intravascular Coagulation. G. Huber,* R. MAson,* C. PEGG,* and J. Norman,* Boston, Mass. (introduced by R. H. Aster).

9. Physiologic and Pharmacologic Responses in Patients Subjected to Cardiac Transplantation. G. GLICK, E. B. Diethrich, S. A. Kinard, and M. E. DeBakey,* Houston, Tex.

10. Sequential Atrioventricular Pacing in Acute Myocardial Infarction. R. C. Leinbach,* D. A. Chamberlain,* J. A. Kastor,* C. E. Vassaux,* R. W. DeSanctis,* and C. A. Sanders, Boston, Mass.

\section{SATURDAY EVENING, MAY 3}

\section{SUBSPECIALT Y MEET INGS}

(The presentation of each paper will be limited to $10 \mathrm{~min}$ )

\section{CARDIOVASCULAR I}

7:30 p.m., Pennsylvania Room II, Haddon Hall Dr. Stephen E. Epstein, Presiding

1. Myocardial Compliance Changes as an Indicator of Cardiac Homograft Rejection. R. R. EcKer,* A. Z. NAJEM,* R. J. Cyrus,* W. R. Webb,** and W. L. Sugg, Dallas, Tex.
2. Assessment of Myocardial Contractility in Man from Ventricular Pressure Recordings. IsRael Mirsky,* R. Curtis Ellison,* and Paul G. Hugenholtz,* Boston, Mass. (introduced by Harry Bass).

3. Comparison of Left Ventricular Volume by the Biplane Cineangiographic Method and the Pressure-Volume Curve Method. C. B. Mullins, D. C. Jones,* and J. H. Mitchell, Dallas, Tex.

4. Effects of Glucagon on Cardiovascular Dynamics and Myocardial Metabolism in the Low Output State. J. GrE- 
Gory, H. Mueller, ${ }^{* *}$ J. GnoJ,* S. Ayres, S. GianNELLI,** and E. ConkLin,* New York.

5. Effect of Glucagon on Electrolyte Excretion in Congestive Heart Failure. J. 'Simanis* and L. I. GoldberG,** Atlanta, Ga.

6. Peripheral Impedance as a Determinant of Cardiac Output following Digitalis and Isoproterenol. A. JAMES Liedtke,* John Buonchristiani,* Edmund SonnenBlick, and Charles Urschel, Boston, Mass.

7. Chronic Anemia and Redistribution of Cardiac Output (C.O.). B. Hoffbrand,* R. Forsyth,* and K. L. MelMoN, San Francisco, Calif.

\section{CARDIOVASCULAR II}

\section{7:30 p.m., Pennsylvania Room I, Haddon Hall Dr. Andrew G. Wallace, Presiding}

1. Reentrant Supraventricular Tachycardia. B. GoldREYER,* J. T. Bigger, JR., and R. Heissenbuttel,* New York.

2. Hemodynamic Effects of Glucagon in Patients with Coronary Artery Disease at Rest and during Mild Supine Exercise. B. H. Greenberg,* B. D. McCallister, and R. L. FRYE, Rochester, Minn.

3. An Ion Transport Defect in Patients with Myocardial Infarction. M. F. Villamil,* E. Simpson,* and C. R. Kleeman,** Los Angeles, Calif.

4. Lysosome Instability in Early Phases of Ischemic Myocardial Injury. M. A. Ricciutti* and A. N. Damato,* Staten Island, N. Y. (introduced by A. F. Debons).

5. Effect of Lidocaine on Left Ventricular Function in Dogs. D. S. Mierzwiak, W. M. Gersony, A. M. Smith,* E. D. Mclaughlin,* and J. H. Mitchell, Dallas, Tex.

6. Myocardial Metabolism in Acute Regional Ischemia. H. B. Barner, M. Jellinek,* and G. C. Kaiser, St. Louis, Mo.

7. Effects of Varying Intensities of Exercise and Bed Rest on Fibrinolytic Activity. D. R. Rosing,* P. Brakman,* D. R. Redwood,* R. E. Goldstein,* G. D. Beiser, and S. E. Epstein, Bethesda, Md.

\section{CARDIOVASCULAR III}

\section{7:30 p.m., Pennsylvania Room III, Haddon Hall Dr. François M. Abboud, Presiding}

1. Angiotensin Receptors. Theodore Goodfriend and ShoeiYN Lin,* Madison, Wis.

2. Differential Effects of Chemoreceptor Stimulation on Cutaneous and Muscular Vessels. M. G. Calvelo,* F. M. Abboud, and W. Abdel-Sayed,* Iowa City, Iowa.

3. Intact Synthesis and Increased Turnover of Norepinephrine- ${ }^{3} \mathrm{H}$ after L-DOPA- ${ }^{-3} \mathrm{H}$ in Dysautonomia. VINCENT DeQuattro* and Leonard Linde,* Los Angeles, Calif. (introduced by John T. Nicoloff).

4. Role of Renin in Homeostasis of Posture. Suzanne Oparil, Carlos Vassaux,* Charles A. Sanders, ** and E. HABER, ${ }^{* *}$ Boston, Mass.
5. Effect of Acute Hypoxia on Neurogenic Vasoconstriction in Man. Donald D. Heistad and Robert C. Wheeler,* Natick, Mass.

6. Hypotensive Neurosecretion of the Carp Urophysis. JEFfrey P. Rogers,* William J. Arnold,* and Willard S. Harris, Chicago, Ill.

7. Treatment of Idiopathic Postural Hypotension with Oral Tyramine (TY) and Monoamineoxidase Inhibitor (MI). M. A. Diamond,* R. H. Murray, ${ }^{* *}$ and P. Schmid, Indianapolis, Ind. and Iowa City, Iowa.

\section{ENDOCRINOLOGY}

\section{7:30 p.m., Carolina Room, Chalfonte Dr. Norman H. Bell, Presiding}

1. Effect of Parathyroid Hormone on the Concentration of 3', 5'-AMP in Bone. L. R. Chase and G. D. AUrbach,** Bethesda, Md.

2. The Effect of Glucocorticoids on Thyrotropin (TSH) Secretion. J. F. Wilber and R. D. Utiger, Chicago, Ill. and St. Louis, Mo.

3. Uremic Bone Disease and Serum Collagen-Stimulating Factor. Joh N R. Handy,* David R. Hobbs,* and Nancy M. Parks,* Augusta, Ga. (introduced by W. H. Chew).

4. Delay in Formation and Maturation of New Bone Matrix in Vitamin D Deficiency. D. Baylink,* J. Wergedal,* M. Stauffer,* and C. Rich,** Seattle, Wash.

5. Reduced Glutathione (GSH) and Thyroglobulin (TG) Proteolysis: Evidence for Particulate Transhydrogenase Activity. R. L. Peake, R. C. Cates,* and W. P. Deiss, JR., ** Galveston, Tex.

6. Abnormalities of $\mathrm{T} 3$ Secretion in Man: Clinical and Pathophysiological Observations Utilizing Gas Chromatographic Techniques. C. S. Holla nder, N. Nihei,* and S. Z. Burday,* Rochester, N. Y.

7. Serum $\mathrm{LH}$ in Abnormal Sexual Development. Harvey Guyda,* Ann Johanson,* and Robert Blizzard,** Baltimore, Md.

\section{GASTROENTEROLOGY}

\section{7:30 p.m., Rutland Room, Haddon Hall Dr. Frank L. Iber, Presiding}

1. Australia Antigen in Acute and Chronic Liver Disease. Ralph Wright,* Robert W. McCollum,* and Gerald Klatskin,** New Haven, Conn.

2. The Prognostic Significance of Subacute Hepatic Necrosis in Acute Viral Hepatitis. J. L. Boyer and G. KLATsKIN, ** New Haven, Conn.

3. Alcoholic Hepatitis: Natural History and Evaluation of Therapy. R. M. Helman,* M. H. Temko,* and H. J. Fallon, Chapel Hill, N. C.

4. Microsomal Drug Metabolism and Portal Pressure. Stanislav Popovic,* Willem tenHove,* and Carroll M. LeEvy,** East Orange, N. J.

5. Effect of Ethanol on Hepatic Microsomal Systems. F. ToBon* and E. Mezey, Baltimore, Md. 
6. Effect of Obstructive Jaundice and of Bile Salts on Activity of Rat Hormone-Sensitive Lipase. JAcQUES I. Kessler and J. L. Brandt,**. Montreal, Canada.

7. Hypersplenism in Cirrhosis: Measurements of Portal Pressure, Spleen Size, and Circulating Blood Cell Disappearance Rates. A. Blackman,* N. Grace,* H. Cha ndler,* F. Iber, and M. Greenberg, Boston, Mass.

\section{INFECTIOUS DISEASES}

\section{7:30 p.m., Windsor Room, Haddon Hall Dr. Marvin Turck, Presiding}

1. Complement-Requiring Neutralizing Antibody; A Rapid Reliable Index of Herpes Simplex Infection in Encephalitis. A. Martin Lerner, David C. Nolan,* and ElizAbeth J. Bailey,* Detroit, Mich.

2. Studies on the Origin of Human Leukocytic Pyrogen (LP). James J. Nordlund,* Richard K. Root, and Sheldon M. Wolff, Bethesda, Md.

3. The Continuous Bacteremia of Lepromatous Leprosy. David J. Drutz, Wen-Hsiung Lu,* and Thomas S. Chen,* Taipei, Taiwan.

4. Pulmonary Clearance of Pseudomonas aeruginosa. P. M. Southern, Jr., B. B. Mays,* A. K. Pierce, and J. P. SAnford, Dallas, Tex.

5. Immunological Response to Pseudomonas Diseases. JAckson G. Crowder and Arthur White,** Indianapolis, Ind.

6. Effect of Alternate Day and Daily Schedules of Corticosteroid Administration on Reticuloendothelial System (RES) Phagocytic Function, and Response to Infection with Candida albicans. D. C. Bird,* and J. N. Sheagren, Bethesda, Md.

7. Reticuloendothelial System Phagocytic Function during Naturally Acquired Human Malaria. John N. SheAGren and Sheldon M. WolfF, Bethesda, Md.

\section{METABOLISM \\ 7:30 p.m., Music Room, Chalfonte \\ Dr. Daniel W. Foster, Presiding}

1. Copper-67 Studies in Wilson's Disease Patients and Their Families. G. Thomas Strickland,* W. M. Beckner,* M. L. Leu,* and Sean O'Reilly,* Taipei, Taiwan (introduced by $\mathrm{R}$. H. Watten**).

2. Temporary Diabetes in Mice, Caused by Encephalomyocarditis Virus (EMV). J. E. CRaighead* and J. Steinke, Burlington, Vt. and Boston, Mass.

3. Chronic Lactic Acidosis in an Adult: A New Syndrome Associated with Altered Redox State of NAD/NADH Coupled Reactions. Karl Sussman, Alan Alfrey,* Wolff Kirsch,* Phillip Felig,* and Paul Zweig,* Denver, Colo.

4. Possible Role of Cyclic Adenosine Monophosphate and Cyclic Guanosine Monophosphate in the Renal Response to Acidosis and Alkalosis. Anthony S. Pagliara* and A. David Goodman, Albany, N. Y.

5. A Two Pool Mechanism for Insulin Secretion in Man. R. L. Lerner* and D. Porte, JR., Seattle, Wash.
6. Growth Hormone and Insulin Metabolism in the Pregnant Macaca mulatta. Daniel H. Mintz, Ronald A. Chez,* and Edgar G. Horger III,* Pittsburgh, Pa.

7. The Effect of Quinine on Human Skeletal Muscle and Jejunal Cation-Sensitive Membrane-ATPase (CSMA) in Normal Subjects (NS) and Patients with Myotonia Congenita (MC), Myotonia Dystrophica (MDA), and Muscular Dystrophy (MDY). Robert H. Herman,** Nicholas J. Di Bella,* Fred B. Stifel, Louis Hagler,* and Norton S. Rosensweig, Denver, Colo.

\section{RENAL AND ELECTROLYTES I \\ 7:30 p.m., Viking Room, Haddon Hall \\ Dr. John H. Dirks, Presiding}

1. Effects of Propionate and Other Organic Anions on the Electrical Properties of Toad Urinary Bladder. IRWIN Singer and Mortimer M. Civan, Boston, Mass.

2. Relationship of Renal Subcapsular Pressure (RSCP) to Wedge Renal Venous Pressure (WRVP) and the Natriuresis of Saline Loading. G. S. ARbUs* and L. A. Hebert, Boston, Mass.

3. The Effect of Transport Inhibitors on Sodium Outflux in Red Blood Cells. Michael J. Dunn, Washington, D. C.

4. Relationships between Erythrocyte Active Transport of Sodium, Lactate Production, and Erythrocyte Sodium Concentration. C. H. Wallas,* J. C. Parker,* H. J. Gitelman,* and L. G. Welt,** Chapel Hill, N. C.

5. Suppression of $\mathrm{Na}$ Diuresis by the Provision of $\mathrm{Cl}$. J. Cohen, J. Chazan, and S. Garella,* Providence, R. I.

6. Effect of Acidosis and Alkalosis on Renal Cortical Glutamate Metabolism. Donald E. Kamm, Rochester, N. Y.

7. Ethacrynic Acid Inhibits Gut Fluid Loss in Cholera. Q. Al Awqati,* W. B. Greenough III, and C. C. J. CarPENTER, Baltimore, Md.

\section{RENAL AND ELECTROLYTES II

$$
\begin{gathered}
\text { 7:30 p.m., West Room, Haddon Hall } \\
\text { Dr. Carl Goldsmith, Presiding }
\end{gathered}
$$

1. Abnormal Regulation of Plasma Tryptophan in Uremia. Alexander Aviram, Paul Gulyassy, and John $\mathrm{H}$. Peters,* San Francisco and Menlo Park, Calif.

2. The Biologic Properties of Cryoglobulins in Glomerulonephritis. Rawle M. McIntosh,* Los Angeles, Calif. (introduced by Carl M. Pearson).

3. Humoral Factors Affecting Renal Growth in Uninephrectomized Rats. H. G. Preuss, E. F. Terryi,* and A. I. Keller,* Pittsburgh, Pa.

4. Renal Function and Structure within $18 \mathrm{Hr}$ following Uninephrectomy. D. Potter, ${ }^{*}$ T. Sakai,* J. Harrah,* and M. A. Holliday,** San Francisco, Calif.

5. Role of Efferent Resistance in Canine Renal Autoregulation. John L. McNay and Youiche Abe,* Atlanta, Ga. 
6. Renal Blood Flow and Renin Secretion. M. Donald Blaufox, Arthur Fromowitz,* C. Meng,* Hyo BoK LeE,* and Milton Elkin,* Bronx, N. Y.
7. Renal Function and Histology after Long-Term FollowUp of Tubular Necrosis. D. T. Lewers, ${ }^{*}$ T. H. Mathew,* J. F. Maher, and G. E. Schreiner, ** Washington, D. C.

\section{SUNDA Y EVENING, MAY 4}

\section{SUBSPECIALTY MEETINGS}

(The presentation of each paper will be limited to 10 min.)

\section{CARDIOVASCULAR I}

\author{
7:30 p.m., Pennsylvania Room II, Haddon Hall \\ Dr. Stephen E. Epstein, Presiding
}

1. Atrial Contraction in Aortic and Mitral Stenosis. D. K. Stotr,* J. D. Bristow, and F. E. Kloster, Portland, Oreg.

2. Calcium Accumulation by Subcellular Fractions of the Failing Rat Heart. J. R. Muir,* N. S. Dhalla,* Josefina Orteza,* and Robert E. Olson,** Pittsburgh, Pa.

3. Erythrocyte Loss with Extracorporeal Circulation. HerBert W. Wallace and William S. Blakemore,* Philadelphia, $\mathrm{Pa}$.

4. Effects of Carotid Sinus Nerve Stimulation (CSNS) on Circulatory Dynamics in the Intact Conscious Dog. S. F. Vatner,* D. L. Franklin, R. L. Van Citters, and E. Braunwald, Seattle, Wash. and San Diego, Calif.

5. Skeletal Muscle in Cardiomyopathy. Merle A. Sande,* Richard R. Carruthers,* Thomas Killip,** S. A. ShafiQ,* and A. T. Milhorat,* New York.

6. Computer-Assisted Digitalis Dosage Programs. Roger W. Jelliffe, Los Angeles, Calif.

\section{CARDIOVASCULAR II}

7:30 p.m., Pennsylvania Room I, Haddon Hall

Dr. Andrew G. Wallace, Presiding

1. The Interaction of Plasma Lipoproteins and Plaque Elastin in Atherosclerosis. Dieter M. Kramsch* and WILliam Holla nder,** Boston, Mass.

2. Electron Microscopic Studies on Platelets from Myocardial Infarction Patients. Irwin J. Schatz and Jeanne RiddLE,* Detroit, Mich.

3. Evaluation of Regional Coronary Venous Sampling in Localized Coronary Artery Obstruction. L. D. BAKER,* J. C. Pomposiello,* G. V. R. K. Sharma,* J. A. Snow,* and J. V. Messer, Boston, Mass.

4. Spontaneous Angina Pectoris (SAP): Hemodynamic and Metabolic Changes. Ezra A. Amsterdam,* Joel H. Manchester,* Harvey G. Kemp, and Richard GorLIN,** Boston, Mass.
5. The Electrophysiological Aspects of Epinephrine and Glucagon-Induced Inotropy. Robert E. Edmands, KaLman Greenspan,** and Charles Fisch, ${ }^{* *}$ Indianapolis, Ind.

6. Clinical Evaluation of the Multiple Dipole Electrocardiogram. J. H. Holt, JR., A. C. L. Barnard,* M. S. LynN,* and H. T. Dodge, Birmingham, Ala. and Houston, Tex.

\section{DERMATOLOGY}

\section{7:30 p.m., West Room, Haddon Hall \\ Dr. Robert E. Kellum, Presiding}

1. Proliferative Cell Compartment in Human Epidermis. N. S. Penneys,* J. E. Fulton, Jr.,* G. D. Weinstein, and P. Frost, Miami, Fla.

2. Complement-Fixing Antibodies in Bullous Pemphigoid. R. E. Jordon, W. M. Sams, JR., and E. H. Beutner,* Rochester, Minn. and Buffalo, N. Y.

3. Morphological and Immunological Studies of Necrotizing Vasculitis in Systemic Lupus Erythematosus (SLE). D. L. Tuffanelli and D. M. Kay,* San Francisco, Calif.

4. Effects of Repeated Subsensitizing Applications of a Contact Sensitizer to the Skin in Man. Edmund D. LowNEY, Richmond, Va.

5. Immunoglobulins and Complement in Skin of Patients with Systemic Lupus Erythematosus. J. P. BAILEY, JR. and H. G. Mealing, Jr.,* Augusta, Ga.

6. Effect of Dermal Perfusion Rate on Percutaneous Penetration In Vitro. W. A. Crutcher, * R. J. Feldmann,* and H. I. Maibach, San Francisco, Calif.

\section{ENDOCRINOLOGY}

$$
\begin{gathered}
\text { 7:30 p.m., Carolina Room, Chalfonte } \\
\text { Dr. Leonard D. Garren, Presiding }
\end{gathered}
$$

1. Metabolic Variations in Sexual Ateliotic Dwarfism: A Basis for Classification. T. J. Merimee, D. Rimoin, J. HALl,* and V. A. McKusick, Baltimore, Md. and Boston, Mass.

2. Medical Treatment of Acromegaly with Progestins. A. M. Lawrence, Chicago, Ill. 
3. New In Vitro Effect of Cortisol: Induction of Growth Hormone Synthesis by Pituitary Cells in Culture. P. Kohler, L. Frohman, W. Bridson,* T. Vanha-Perttula,* and J. Hammond,* Bethesda, Md. and Buffalo, N. Y.

4. Stimulation of DNA Synthesis in Adrenal Glands by ACTH. Hideo Masui* and Leonard D. Garren, La Jolla, Calif.

5. Occurrence of a Catecholamine Oxidase in Mammalian Smooth Muscles. Mario A. Inchiosa, JR. and Irmina B. RodRIGUez,* New York.

6. Nonautonomous Behavior of Plasma Growth Hormone in Active Acromegaly. S. Feld,* R. KJellberG,* and B. Kliman, Boston, Mass.

\section{GASTROENTEROLOGY}

\section{7:30 p.m., Rutland Room, Haddon Hall \\ Dr. Jerry S. Trier, Presiding}

1. The Adaptive Response of the Lower Esophageal Sphincter. Sidney Cohen and Lauran D. Harris,* Boston, Mass.

2. Taurocholate and Oleic Acid Absorption by Hamster Jejunum. Stuart Gordon* and Fred Kern, Jr.,** Denver, Colo.

3. Influence of Pentagastrin on Mucosal Blood Flow in Canine Fundic and Antral Pouches. J. Rudick, J. L. Werther,* M. A. Chapman,* D. A. Dreiling,** and H. D. Janowitz,** New York.

4. Jejunal Bicarbonate and Sodium Transport in Normal Man. L. A. Turnberg, ${ }^{*}$ F. C. Rector, and J. S. FordTRAN, Dallas, Tex.

5. Inhibition of Intestinal Lactase. A Possible Role in Lactose Intolerance. D. H. Alpers, Boston, Mass.

6. Use of Gases for Study of the Intestinal Circulation. M. D. Levitr,* Minneapolis, Minn. (introduced by I. D. Wilson).

\section{HEMATOLOGY}

\section{7:30 p.m., Vernon Room, Haddon Hall \\ Dr. Marcel E. Conrad, Presiding}

1. Role of ATP, Ca, and Mg in Red Cell Membrane Deformability. P. L. LACELlE and R. I. WEED, Rochester, N. Y.

2. A Normal Serum Protein That Removes $C^{\prime} 3$ from Red Cells. N. Abramson, C. A. Alper, F. S. Rosen, and J. H. JANDL,** Boston, Mass.

3. Enzymatic Regulation of 2,3-Diphosphoglyceric Acid (2,3-DPG) Levels in the Erythrocytes. D. R. HarkNESS, Miami, Fla.

4. Acid-Serum Lysis of Paroxysmal Nocturnal Hemoglobinuria (PNH) WBC's, and Formation of PNH-Like Lesion in Normal WBC's. L. J. Essig* and L. H. BRUBAKer, Columbus, Ohio and Columbia, Mo.
5. Cobalt Excretion Test for the Detection of Iron Deficiency and Idiopathic Hemochromatosis. L. S. VALberg, D. Olatunbosun,* J. Ludwig,* and W. E. N. CoRbett,* Kingston, Canada.

6. Primary Platelet Dysfunction: Differentiation from Abnormality Induced by Aspirin. Mervyn A. SAHUD* and Paul M. Aggeler, ${ }^{* *}$ San Francisco, Calif.

\section{IMMUNOLOGY}

$$
\begin{gathered}
\text { 7:30 p.m., Viking Room, Haddon Hall } \\
\text { Dr. John P. Leddy, Presiding }
\end{gathered}
$$

1. The Effect of Antigen Density on Hemagglutination. Leon W. Hoyer and Norma C. Trabold,* Rochester, N. Y.

2. The Gastric Lesion That Occurs in Immunoglobulin (Ig)-Deficient Patients. J. J. Twomey, P. H. Jordan, JR.,* A. H. Laughter,* H. Meuwissen,* and R. A. Good,** Houston, Tex. and Minneapolis, Minn.

3. Immunosuppressive Potency of Antithymus Serum Prepared with Saline-Soluble Thymus Antigens. H. Nagaya and H. O. Sieker, ${ }^{* *}$ Durham, N. C.

4. Anti-IgA Antibodies in Patients with Selective IgA Deficiency and Connective Tissue Diseases. JAmEs T. Cassidy, Ross Petty,* Ann Burt,* and Donita Sullivan,* Ann Arbor, Mich.

5. The Cellular Basis of Drug-Induced Immunological Tolerance. Amira ManY* and Robert S. Schwartz, Boston, Mass.

6. Complement Fixation Activity of Purified Paraproteins from Patients with Waldenstrom's Macroglobulinemia. M. Michael Glovsky* and H. H. Fudenberg, San Francisco, Calif.

\section{METABOLISM}

\section{7:30 p.m., Music Room, Chalfonte \\ Dr. Robert I. Levy, Presiding}

1. Vitamin E and Experimental Porphyria. Hari S. MURTY* and P. P. NAIr,* Baltimore, Md. (introduced by Albert I. Mendeloff**).

2. The Effect of Ethanol on the Secretion of Very Low Density Lipoprotein (VLD) from Livers of Fed and Fasted Rats. J. M. Felts,* A. Bezman-Tarcher, and T. F. Whayne, JR., San Francisco, Calif.

3. Effect of Ethanol on Bile Acid Metabolism. A. LefÈvre and C. S. LIEBER, New York.

4. Application of Optical and Immunologic Techniques to the Question of Circulating $\beta$-Apoprotein in Normals and Patients with Abetalipoproteinemia. A. M. Gotro,* R. I. Levy, M. E. Birnbaumer,* and D. S. Fredrickson,* Bethesda, Md.

5. Reciprocal Control of Lipoprotein Lipase and HormoneSensitive Lipase. R. L. Patten,* Montreal, Canada (introduced by $\mathrm{C}$. $\mathrm{H}$. Hollenberg**). 
continued

6. Balance of Individual Amino Acids across Forearm Muscle. T. Pozefsky, P. Felig, J. S. Soeldner, and G. F. Cahill, JR., ${ }^{* *}$ Boston, Mass.

\section{NEOPLASIA}

7:30 p.m., Solarium, Haddon Hall

\section{Dr. Paul P. Carbone, Presiding}

1. Asparaginyl-Transfer RNA of Asparaginase-Sensitive and -Resistant Mouse Lymphomas. R. C. GALlo, J. Longmore,* and R. H. Adamson,* Bethesda, Md.

2. Immunological Impairment in SJL/J Mice with a Hodgkin's-Like Tumor: Diminished Granuloma Formation Around Schistosome Eggs. Kenneth S. Warren, Cleveland, Ohio.

3. Thymine Riboside Inhibition of Lymphocyte Mitosis. Albert A. Keshgegian,* Lorraine F. Meisner,* and John H. Frenster, Palo Alto, Calif.

4. In Vitro Uptake of Tritiated Thymidine and Uridine in Acute Leukemia. W. H. Cheung and A. SAwitsky,** New Hyde Park, N. Y.

5. Hypercalcemia of Neoplasia: A Model System. B. F. Rice, R. Ponthier,* M. C. Miller III,* and L. M. Roth,* New Orleans, La.

6. Treatment of Metastatic Breast Cancer with AminoGlutethimide. T. Hall,** J. Barlow,** C. Griffiths,* and Z. SABA,* Boston, Mass.

\section{PATIENT CARE}

\section{7:30 p.m., Garden Room, Haddon Hall \\ Dr. Robert C. Buxbaum, Presiding}

1. The Day Care Rehabilitation Center: An Intermediate Care Facility. H. Bienenstock, S. Forster,* E. Desser,* and P. MA,* Brooklyn, N. Y.

2. An Application of Computer Techniques to the Evaluation of Patterns of Physiologic Abnormality in Patients with Severe Sepsis. J. H. Siegel and R. M. Goldwyn,* New York.

3. Analysis of Patient Care by an Interservice Audit of Serum Calcium Determinations. S. ReIchmaN** and J. Manis,* New York.

4. Evaluation of Computer Acquisition of Patient Medical Histories. Jerome H. Grossman,* G. Octo Barnett,** Michael T. McGuire,* Robert A. Greenes,* and David Swedlow, Boston, Mass.

5. Medical Practice in the Urban Core: Survey of G.P.'s in the London Borough of Camden. Victor W. Sidel, Peter Mansfield,* and Margot Jefferys,* Boston, Mass.

6. Employment Practices as Deterrents to Rehabilitation of Patients with Cardiovascular Illness. James Buxman,* Robert E. Drickey,* and David Werdegar, San Francisco, Calif.

\section{PULMONARY}

\section{7:30 p.m., Pennsylvania Room III, Haddon Hall}

\section{Dr. Alan K. Pierce, Presiding}

1. Lung Elastic Recoil and Airway Resistance as Factors in Chronic Airway Obstruction. R. W. B. Penman and L. Begley,* Lexington, Ky.

2. Roentgenographic Method for Studying Small Airways In Vivo: Effects of Parasympathetic and Sympathetic Nerve Stimulation. G. Cabezas,* J. Austin,* G. Kopf,* and J. NADEL, San Francisco, Calif

3. The Effect of Nasal and Nasopharyngeal Irritation on Airway Resistance in Man. J. KaufmaN* and G. W. WRIGHT,* Cleveland, Ohio (introduced by M. Rosenthal).

4. Measurement of Functional Transpulmonary Shunting in Normal Man and Patients with Pulmonary Embolism. H. William Strauss,* Peter J. Hurley,* Buck A. Rhodes,* and Henry N. Wagner, JR.,** Baltimore, Md.

5. Factors Affecting Physiological Dead Space in Man. A. Lifshay,* C. W. Fast,* J. B. Glazier, and J. F. MurRAY,** San Francisco, Calif.

6. Quantitation of Respiratory Response to Hypoxia in Man. R. KronenberG,* F. N. Hamilton,* R. Gabel,* R. Hickey,* D. J. C. Read,* and J. Severinghaus,** San Francisco, Calif.

\section{RENAL AND ELECTROLYTES}

$$
\begin{gathered}
\text { 7:30 p.m., Windsor Room, Haddon Hall } \\
\text { Dr. John H. Dirks, Presiding }
\end{gathered}
$$

1. Micropuncture Study of Superficial and Juxtamedullary Nephrons in the Mammalian Kidney. Rex L. Jamison, St. Louis, Mo.

2. Reabsorptive Response of the Dog Distal Nephron to Extracellular Volume Expansion and to Furosemide Diuresis. J. F. SEelY* and J. H. Dirks, Montreal, Canada.

3. Autoradiographic Study of Organic Acid Transport in Rat Kidney. R. P. Wedeen, S. O. Thier, B. Bordier,* and B. Weiner,* Boston, Mass. and New York.

4. Effect of Extracellular Volume Expansion (VE) on Proximal Tubular Sodium Reabsorption and Distribution of Renal Blood Flow (RBF) and Glomerular Filtrate (GFR) in the Dog. J. H. Stein, L. J. Barton,* H. Mandin,* L. H. Lackner,* F. C. Rector, JR., and D. W. Seldin,** Dallas, Tex.

5. Effects of Amiloride, Ouabain, and Furosemide upon Distal Tubular Function in the Rat. C. G. Duarte, F. Chomety,* and G. Giebisch,* New York.

6. Volume-Mediated Regulation of Furosemide Diuresis. J. R. Clapp, K. Nakajima,* G. A. Nottebohm,* and R. R. Robinson, Durham, N. C. 


\title{
The Association of American Physicians
}

\author{
82 ND ANNUAL MEETING
}

TUESDA Y, MAY 6

\author{
M O R N I N G \\ 9:00 a.m., Pennsylvania Room, Haddon Hall \\ GENERAL BUSINESS
}

THE PRESIDENT'S ADDRESS

SCIENTIFIC SESSION

1. Pathogenesis of Emphysema in Antitrypsin Deficiency. John A. Pierce,* Arthur Z. Eisen,* and Harish K. Dhingra,* St. Louis, Mo. (introduced by Carl V. Moore).

2. Observations on the Plasma Kallikrein System during Myocardial Ischemia. B. Pitt,* J. Mason,* C. R. Contr,* and R. W. Colman,* Baltimore, Md. and Boston, Mass. (introduced by Richard S. Ross).

3. Diagnosis of Congenital and Acquired Cardiovascular Disease by Radioisotopic Angiocardiography. JoSEPH P. Kriss* and Philip Matin,* Palo Alto, Calif. (introduced by David Rytand).

4. The Regulation of Hemoglobin Affinity for Oxygen in Man. Claude Lenfant,* John Torrance,* and Clement A. Finch, Seattle, Wash.

5. Defective Sulfation Factor Generation: A Possible Etiological Link in Dwarfism. W. H. Daughaday, Z. LARoN,* and J. N. Heins,* St. Louis, Mo. and Petah Tiqva, Israel.

6. Identification of a Naturally Occurring Goitrogen in Water. Eduardo Gaitan,* Donald P. Island,* and Grant W. Liddle, Cali, Colombia and Nashville, Tenn.

7. The Mechanism of the Hypoglycermic Action of 4Pentenoic Acid. R. Bressler and K. Brendel,* Durham, N. C.

8. "Abacterial" and Bacterial Pyelonephritis: Detection of Bacterial Antigen. Shigehisa Aoki,* Sadao Imamura,* M. AokI,* and W. R. MCCABE,* Boston, Mass. (introduced by C. S. Keefer).

9. A Specific Antigen and Antibody in Acute Poststreptococal Glomerulonephritis. Kurt Lange,* Martin Semar,* Antonia Ty,* and Gerhard Treser,* New York (introduced by Rachmiel Levine).

10. Treatment of Varicella-Zoster with Cytosine Arabinoside. T. Hall,* C. Wilfert,* N. Jaffe,* D. TragGis,* S. Lux,* P. Rompf,* and S. KAtz,* Boston, Mass. and Rochester, N. Y. (introduced by William S. McCann).

\section{A F T ER NOON}

2:00 p.m., Pennsylvania Room, Haddon Hall

\author{
PRESENTATION OF \\ THE GEORGE M. KOBER MEDAL \\ TO DANA W. ATCHLEY \\ BY
}

DICKINSON W. RICHARDS

\section{SCIENTIFIC SESSION \\ (continued)}

11. The Course of Asymptomatic Diabetes in Young People. Stefan S. Fajans, John C. Floyd, JR.,* Sumer Pek,* and Jerome W. Conn, Ann Arbor, Mich.

12. Prolactin-Dependent Rat Mammary Cancer: A Model for Man? O. H. Pearson, O. Llerena,* L. Llerena,* A. Molina,* and T. Butler,* Cleveland, Ohio.

13. Intergenic Complementation of Two $\mathrm{X}$-Linked Genes by Hybridization of Mutant Human Fibroblasts. J. EdwIN Seegmiller,* Marcello Siniscalco,* Harold $P$. Klinger,* Harry Eagle,* Hilary Koprowski,* and Wilfred Y. Fujimoto,* Bethesda, Md., Bronx, N. Y., Philadelphia, $\mathrm{Pa}$., and Leiden, Holland (introduced by J. E. Rall).

14. A Genetic Study of Cystic Fibrosis of the Pancreas in Cell Culture. Alexander G. Bearn and B. Shannon Danes,* New York.

15. Adjuvant-Induced Arthritis: An Immunologic Model of Articular and Connective Tissue Disease. CARL M. PEARson, Brian B. Newbould,* Kunio Tanaka,* and Michael W. Whitehouse,* Los Angeles, Calif.

16. Patterns of Cold Agglutinin (CA) Production. Nicolas Costea,* Vincent Yakulis,* and Paul Heller, Chicago, IIl.

17. The Role of Serum Hepatitis Virus in Chronic Liver Disease. Alfred M. Prince,* R. Leslie Hargrove,* and Graham H. Jefrries, New York (introduced by Benjamin Alexander).

18. Reconstitution of Immunologic Capacity and Alleviation of Aregenerative Pancytopenia by Bone Marrow Transplantation. R. A. Good, H. J. Meuwisser,* R. A. Gatti,* and R. C. Hong,* Minneapolis, Minn.

19. Generalized Fasciculations and Muscular Stiffness of Peripheral Nerve Origin. W. E. Wallis* and F. Plum, New York.

20. Blood Pressure in Giraffe Cerebral Vessels. R. L. VAN Citters,* D. Franklin,* T. Patrick,* S. F. Vatner,* and J. V. WArren, Seattle, Wash., LaJolla, Calif., and Columbus, Ohio. 


\title{
WEDNESDAY MORNING, MAY 7
}

\author{
9:00 a.m., Windsor Room, Haddon Hall
}

\section{THE DISTINGUISHED LECTURE}

\section{PLASMA LIPOPROTEINS: MICELLAR MODELS AND MUTANTS BY}

DONALD S. FREDRICKSON

\section{SCIENTIFIC SESSIONS \\ (concluded)}

21. Splanchnic Metabolism in Von Gierke's Disease. R. J. Havel, E. O. Balasse,* H. E. Williams,* J. P. Kane,* and N. Segel,* San Francisco, Calif.

22. Red Cell Cholesterol Content: A Manifestation of the Serum Affinity for Free Cholesterol. R. A. Cooper* and J. H. JA NDL, Boston, Mass.

23. Red Cell (RBC) Energy Metabolism in Uremic Subjects. I. Relationship of Adenosine Triphosphate (ATP) Content to Extracellular Phosphate $\left(P_{1}\right)$. M. A. Lichtman,* D. R. Miller,* and R. I. Weed,* Rochester, N. Y. (introduced by L. E. Young).
24. Respiratory Alkalosis and Alcohol Withdrawal. Sidney M. Wolfe,* Jack Mendelson,* Motor Ogata,* Maurice Victor,* Warren Marshall,* and Nancy Mello,* Bethesda, Md. and Cleveland, Ohio (introduced by Robert S. Gordon, Jr.).

25. Effects of Mithramycin on Paget's Disease of Bone. Will G. Ryan,* Theodore B. Schwartz,* and Charles P. Perlia,* Chicago, Ill. (introduced by Richard B. Capps).

26. The Enzymatic Conversion of Hemoglobin to Bilirubin. Raimo Tenhunen,* Harvey S. Marver,* and Rudi Schmid, San Francisco, Calif.

27. Stimulation of Hepatic Porphyrin Synthesis in Tissue Culture by Sera of Patients with Acute Porphyria. A. Kappas, C. S. Song,* S. Sassa,* and R. D. Levere,* New York.

28. Fetal Erythropoiesis: Erythropoietin Effects on Cultured Cells. R. A. Rifkind,* D. Chui,* M. Djaldetti,* and P. A. Marks, New York.

29. Acquired Hemophilia. N. Raphael Shulman and Richard J. Hirschman,* Bethesda, Md. 


\section{Exhibitors}

Booth No.

E2, E3, E4 Aвbott Laboratories

K8 Academic Press Inc.

H2 Advanced Instruments, Inc.*

J2 American Optical Corporation, Medical Division

H10 Amicon Corporation

G5 Appleton-Century-Crofts

A3 Baird-Atomic, Inc.

K9 Beck Industries, Inc.

K4 Beckman Instruments, Inc.*

F10 Bio-ScIENCE LABORATORIES

K2 Brookline Instrument Co.

D9 Certified Blood Donor Service, Inc.

I8 Clifford Instruments, Inc.

L1 Warren E. Collins, Inc.

E8, E9 Coulter Electronics, Inc.

B4 F. A. Davis Company

L7 The Dikewood Corporation

A5, A6 Electronics for Medicine, Inc.

D7 Excerpta Medica Foundation

H5, H6 Fisher Scientific Company

I5 Gilford Instrument Laroratories, Inc.*

G2 Grune \& Stratton, Inc.*

A9 Gulton Medical Instruments

B2 Hoeber Medical Division, Harper \& Row, Publishers, Inc.

H4 Institute for ScIEnTIfic Information

F2, F3 Instrumentation Associates, Inc.

I3, I4 InStrumentation Laroratory Inc.*

G3 Intercontinental Medical Book Corp.

J8 Iso/Serve, Division of Cambridge Nuclear Corporation

L4 Kallestad Laboratories, INC.

L6 Kalmedic Instruments, Inc.

F9 Lamb Engineering Associates
Booth No.

E5 Lea and Febiger*

C2, C3 E. LEITZ, InCORPORATED*

H9 Lexington Instruments Corporation

C1 J. B. Lippincott Company

I2 Little, Brown and Company

F4 The London Company

G4 McGraw-Hill Book Co., Blakiston Division

C4 The Macmillan Company*

A8 Mallinckrodt/Nuclear

E10 The C. V. Mosby Company

I10, J10 New England Nuclear, Biomedical Assay Laboratories Division

I9 Nikon, Inc., Division Ehrenreich PhotoOptical Industries, Inc.

G6 Olympus Corporation of America

F6 Organon Inc.

J4 Oxford University Press, Inc.*

B8, B9 Packard Instrument Co., Inc.

B1 Pharmacia Fine Chemicals, Inc.

D4 Picker Nuclear

C8, C9 Polaroid Corporation

B3 Plenum Publishing Corporation

A7 Precision Systems

D5, D6 W. B. Saunders Company

H3 Scientific Research Instruments Corporation

I6 Ivan SoRvall, Inc.*

A3 Technical Operations, Joyce, Loebl \& Co., Inc.

D2, D3 Technicon Corporation*

A4 United Medical Laboratories, Inc.

J9 Voiceprint Laboratories, Division of FarRington Mfg. Co.

E6 The Williams \& Wilkins Co.

f5 Year Book Medical Publishers*

Special Area Coca-Cola USA*

\footnotetext{
* See advertisement in this issue.
} 